\title{
Special aspects of Ukrainian schoolchildren's eating behavior
}

\author{
Podrigalo L.V. ${ }^{1,2}$, Iermakov S.S. ${ }^{3}$, Avdiievska O.G. ${ }^{1}$, Rovnaya O.A. ${ }^{2}$, Demochko H.L. ${ }^{4}$ \\ ${ }^{1}$ V. N. Karazin Kharkiv National University, Ukraine \\ ${ }^{2}$ Kharkiv State Academy of Physical Culture, Ukraine \\ ${ }^{3}$ Kazimierz Wielki University, Bydgoszcz, Poland \\ ${ }^{4}$ Kharkiv National Medical University, Ukraine
}

\begin{abstract}
Purpose:

in questioning 408 schoolchildren (15-16 and 17-18 years' age) participated. Distribution by sex was practically equal: $56.62 \%$ were girls and $43.38 \%$ - boys. The questionnaire included questions about frequency of eating some food during recent 30 days. Separate block of questions was devoted to eating habits and presence of the so-called "food trash” in diet. The bent to alimentary diseases was assessed by incidence of excessive body mass in respondents' families.

Results: $\quad$ The determined food consumption permitted to assume the presence of certain eating stereotype: for boys it is directed at development o muscular mass and for girls - mainly of limiting character, connected with diets for correction of constitution. Analysis of some food eating frequency permitted to mark out alimentary risk factors, which require correction and prophylaxis.

Conclusions: the found special aspects of eating behavior permit to assess children's health state as pre-nosology of alimentary genesis, manifested in excessive body mass, deficit of essential vitamins, minerals and food fibers; functional disorders of digestion.

Keywords: eating, schoolchildren, diet, eating behavior, physical activity.
\end{abstract}

\section{Introduction}

The existing social-economic situation in Ukraine facilitates increase of children's pre-nosological states of health [34]. In the worked out prophylaxis programs optimization of eating takes important place. It permits to substantially raise children's adaptation potential, ensure organism with required biologically active substances [2, 40]. As on to-day eating is considered to be one of the most important life components, conditioning health [7].

Turconi et al. [41] studied eating habits and behavior of Italian adolescents. Among the tested, persons with unhealthy eating and low knowledge in this field prevailed. Scientists from Iran [27] found that increased physical activity and consumption of milk food facilitate reduction of body mass index. Influence of increased motor functioning on body composition is noted also in works of Polish authors [18, 20]. Rather wide scale research [6] was devoted to study risk factors of chronic diseases in USA secondary school pupils. Among them substantial place is taken by factors, connected with eating. In other works the parents' role in formation of children's eating habits, is underlined [21]. Important factor is also environmental conditions, which influence on children's and adolescents' eating [19].

Eating habits are closely connected with body mass and children's way of life [4]. Disordered eating behavior and messy food influence on adolescents' body composition [9, 23, 37]. Adolescents-girls are seriously troubled and unsatisfied with their boy shapes. It is a potential mediator in changing their eating behavior [30]. Especially dangerous is influence of food commercials in

\footnotetext{
(C) Podrigalo L.V., Iermakov S.S., Avdiievska O.G., Rovnaya

O.A., Demochko H.L., 2017
}

doi:10.15561/18189172.2017.0304 primary school on children's consuming habits [24].

In opinion of Hummel and Hoffmann [16] eating behavior is a complex phenomenon. With its assessment it is necessary to consider cause-effect dependences between food consumption and health. Population studies, conducted in different countries [10, 13, 38] proved significance of eating behavior as mean of diet optimization.

The purpose of the research is analysis of school age children's eating behavior.

\section{Material and methods}

Participants: as source material we used results of anonym questioning of 408 schoolchildren - pupils of $9^{\text {th }}$ (15-16 years' age) and $11^{\text {th }}$ (17-18 ${ }^{\text {th }}$ years' age $)$ form. Distribution by sex was practically equal: $56.62 \%$ were girls and $43.38 \%$ - boys.

The research was conducted in compliance with WMA Declaration of Helsinki - Ethical Principles for Medical Research Involving Human Subjects, 2013 [44].

The design of the research implied questioning. The questionnaire included questions about frequency of eating some food during recent 30 days. Separate block of questions was devoted to eating habits and presence of the so-called "food trash" in diet. The bent to alimentary diseases was assessed by incidence of excessive body mass in respondents' families. The research was conducted in spring. It permitted to assume that in diet there was variable assortment of food.

Statistical analysis of the received data was fulfilled with the help of licensed Excel and SPSS programs. Statistical processing included application of variation statistic indicators as well as parametric and nonparametric parameters. 


\section{Results}

Study of some food products' eating frequency permits to sufficiently exactly assess variability and completeness of diet. It also permits to prognosticate food influence on functional state of the research participants [35].

The fulfilled analysis showed some gender specific features of main food products' eating. Meat is confidently $(\mathrm{p}<0.05)$ more frequent in daily diet of boys - 31.79 $\pm 3.55 \%$ (girls- $21.78 \pm 2.91 \%$ ). Though, girls eat meat more frequently 2-3 times a week- 50.00 $\pm 3.53 \%$ (boys - 36.99 $\pm 3.68 \%$ ). At the same time boys oftener prefer everyday eating of cooked sausages and frankfurters - 26.47 $\pm 3.39 \%$ (girls - $17.83 \pm 2.53 \%$ ). In respect to smoked sausages the situation is opposite: $83 \pm 2.53 \%)$. In respect to smoked sausages the situation is opposite: girls informed that they do not eat them at all $-28.14 \pm 2.97 \%$ of girls informed that they do not eat them at all (boys $18.34 \pm 2.99 \%)$.

Fish is present in boys' diet the most frequently. $33.57 \pm 4.01 \%$ of boys (girls $-22.91 \pm 2.80$ ) \% said that they eat it regularly. $17.18 \pm 2.51 \%$ of girl against $0.71 \pm 0.71$ do not eat fish at all.

Certain distinctness was found in analysis of milk and milk food consumption, which are irreplaceable in children's eating. With absence of noticeable distinctions in frequency of everyday consumption, girls' monthly diet contained these products oftener: $(10.43 \pm 2.02 \%)$ against $(4.76 \pm 1.65 \%)$. At the same time they oftener eat fermented milk products: $(45.89 \pm 3.29 \%)$ against $(34.68 \pm 3.63 \%)$, $(\mathrm{p}<0.05)$.

This assumption is proved by analysis of fresh vegetables and fruits' eating. Everyday consumption of fresh vegetables is oftener among girls: (76.52 $\pm 2.80 \%)$ against $(63.58 \pm 3.57 \%)$. The same tendency was observed in everyday consumption of fresh fruits: $(76.75 \pm 2.80 \%)$ against (64.71 $\pm 3.68 \%)$. With it, boys much oftener noted full absence of fresh vegetables and fruits in their diets.

Considering the age of our respondents it was interesting to compare frequency of confectionary consumption. It was found that boys' eating of candies is confidently more frequent: $(31.79 \pm 3.55 \%)$ against $(21.78 \pm 2.91 \%)$. Girls eat these products regularly mainly

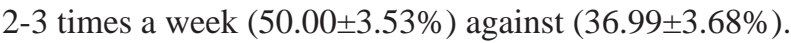

Concerning pastries and other fancies we did not find substantial differences by gender belonging. About 20\% of respondents said about everyday eating and 40\% about regular.

Analyzing consumption of ice-cream, mayonnaises, ketchup and sauce we found practically no gender distinctions. But prevalence of these products in diets also causes certain trouble. Nearly $30 \%$ of children informed about everyday eating of ice-cream and $40 \%$ - about its regular presence in diet.

Only $16 \%$ of children informed about everyday consumption of sauces, ketchups and mayonnaises and $25-30 \%$ - about regular.

Definite distinctions were determined in comparison of food consumption in respect to age. For example, older girls pointed that they eat less meat everyday:
$(40.95 \pm 4.82 \%)$ against $(53.60 \pm 4.48 \%),(p<0.05)$. In older boys regular eating of smoked sausages is less expressed: $(12.24 \pm 4.73 \%)$ against $(30.83 \pm 4.23 \%),(\mathrm{p}<0.05)$. Besides, $11^{\text {th }}$ form girls noted that they more regularly eat curd than younger schoolgirls, accordingly: (39.22 $\pm 4.86 \%)$ against $(26.19 \pm 3.93 \%),(p<0.05)$. At the same time consumption of fermented milk products in general is oftener in junior schoolgirls: (53.97 $\pm 4.46 \%)$ against (36.19 $\pm 4.71 \%)$, $(p<0.05)$. Though about regular consumption of such products senior schoolgirls informed: (41.90 $\pm 4.84 \%)$ against $(22.22 \pm 3.72 \%),(p<0.05)$. Besides, in younger group everyday ice cream consumption was more frequent: $(44.44 \pm 4.44 \%)$ against $(22.12 \pm 4.09 \%),(p<0.05)$.

Much more frequent eating of pastries and fancies was in $9^{\text {th }}$ form girls. In $11^{\text {th }}$ form girls the frequency of such products' consumption was $(27.42 \pm 4.02 \%)$ against $(12.50 \pm 3.26 \%),(p<0.05)$

Separate block of questions was devoted to consumption of the so-called "Food trash". The received data permits to say that such products are rather popular among schoolchildren. Besides, the presence of certain gender specific features was found. Chips and baked breads are confidently more frequent in boys eating: $(22.67 \pm 3.20 \%)$ of them informed about regular eating such food; girls, on the contrary oftener informed about full denial of such products $(39.13 \pm 3.23 \%)$ against $(19.77 \pm 3.05 \%)$

At the same time $9^{\text {th }}$ form pupils consume chips and baked breads everyday oftener then $11^{\text {th }}$ form pupils $(9.76 \pm 2.69 \%)$ against $(2.04 \pm 2.04 \%),(\mathrm{p}<0.05)$.

Fast food products are confidently oftener consumed by boys (11.18 $\pm 2.42 \%)$ against (3.04 $\pm 1.14 \%)$. Girls much oftener note their full absence in diet. Concerning street food eating (shawarma, hot-dogs, pies) situation also can not be called favorable. Only $1-2 \%$ of schoolchildren informed about everyday consumption of such food. More than 50\% noted that they do not consume such food at all. However, everyday consumption of such food is more frequent among boys: (15.20 $\pm 2.75 \%)$ against $(3.91 \pm 1.28 \%)$. Girls much more frequently refuse street food at all: it was informed by $(71.74 \pm 2.98 \%)$ of girls against $(47.37 \pm 3.83 \%)$ of boys. Results of fast food consumption frequency confirm their higher popularity among boys. For example $11.24 \pm 2.44 \%$ of boys informed about their regular presence in diet. It is much higher than in girls $(3.93 \pm 1.29 \%)$.

In order to approximately assess possible disorders of alimentary status we analyzed prevalence of excessive body mass in respondents' families. It was found that in pupils' parents it is met more frequently: (28.65 $\pm 3.27 \%)$ informed about its presence in fathers and $(22.40 \pm 3.02 \%)$ - in mothers. Besides, $41.67 \pm 3.57 \%$ of the questioned proved excessive body mass in grandmothers and grandfathers.

\section{Discussion}

Study of main food products consuming frequency shall be carried out, considering inter-connections in system, "eating-health”. Special aspects of any diet are 
connected with specific characteristics of health and depend on knowledge in this field. Analysis of primary school age children's eating [32] showed the deficit of main food substances and average level of knowledge in this field. The highest quantity of knowledge gaps was found with assessment of role of different food groups.

The applied method of assessment of food consumption frequency is commonly accepted and sufficiently precise that is rather important in studies of eating. For example, Humphries L.L. и Gruber J.J. [17] used the method of 24 hours analysis of eating, studied eating behavior and control of university students' body mass. They found great specific weight of errors of situation by respondents. It requires correction of the received information.

Pilot study of eating organization in Italian schools [37] points at high incidence of diseases, connected with eating disorders. It requires realization of prophylaxis and educational programs.

The found by us more frequent consuming of meat and fish products by boys illustrates increase of irreplaceable amino acids. Refusal of smoked food by girls is a manifestation of healthy orientation of eating (considering great quantity of food ads in smoked food).

Such distribution of food consumption (as main source of proteins) permits to assume the presence of certain eating stereotype: for boys - directed at development of muscular mass; for girls - mainly of restrictive character, connected with demand and desire of body constitution's correction. About the presence of stereotype Martinchik A.N., Maev I.V., Ianushevich O.O. [26] informed, when they studied eating behavior of adolescents, influencing on their health.

Similar results were received also in other works Chang Y.-J., Lin W., Wong Y. [5] The authors studied correlations of eating, eating behavior and health. In $17.11 \%$ of Taiwan secondary schools disorders of eating behavior were proved. Especially frequent eating behavior disorders are in adolescents, who follow limiting diets. They result in deficit of energy, proteins, carbohydrates, zinc, vitamins B6 and B12. Disorders of eating behavior were assessed as risk factor for digestion.

Visser J., Notelovitz T., Szabo C., Fredericks N. [42] studied incidence of eating behavior disordering and weight loss in Jude girls-adolescents. They found that every fifth participant had wrong eating behavior. Every third girl considered her weight excessive. They also proved great incidence of restrictive diets. More than 60\% of the participants used them and 19.1\% applied extreme weigh loss methodic. Close connection of eating behavior, eating and knowledge in this field was proved by Dixit S. и др. [8]. These authors analyzed the state of girlsadolescents, living in India, in countryside. Insufficient eating is a risk factor for health and can cause obstetric complications in the future.

Certain eating stereotype, mentioned in our research, is also proved by analysis of milk and milk products consumption. Increase of fermented milk share in diet reflects orientation on healthy eating, connected with restriction of fats.
Hart M. [14] thinks that eating behavior disordering. It is the main reason of digestive problems, especially of restrictive character. Its normalization ensures prophylaxis of diseases.

Comparative analysis of fresh vegetables and fruits consumption also illustrates certain specific features of eating. Earlier we have already assumed that orientation on healthy eating differs depending on sex. These facts permit to assume great risk of vitamins' deficit, as well and mineral substances and food fibers in boys. The results, received by us prove eating behavior data of other authors. For example, Oosthuizen D., Oldewage-Theron W., Napier C. [38] analyzed eating structure of primary and secondary school age children. They determined the most frequently consumed food products; assessed correlations between knowledge in this field and food consumption. The diets, they studied, had expressed carbon-hydrate character, with high content of refined sugar and fats and insufficient consuming of beans vegetables and fruits.

Feldman R. H. L., Mayhew P. C. [11] in their promising work studied eating behavior, consumption of meat and sodium. Their regression analysis proved prognostic significance of the studied factors and their contribution in health.

Sharkey J. R., Haines P. S., Zohoori N. [39] proved the presence of correlations between peculiarities of eating and health disorders. The persons with high eating risk have functional disorders 2.4 times more frequently. They also made conclusion about eating characteristics' importance as screening for required correction.

Bordi P. L., Cranage D. A., Lambert C., Smith J. [3] studied eating behavior of secondary school, age children. They assessed the quantity of food intakes, habits and proclivities, connected with eating. They found wrong eating regimes (the most often it was missing of breakfast). Eating habits were connected with preference of certain food.

The available information about confectionary consumption can also be assessed as unfavorable in respect to health: excess of sweets is a risk factor for digestion and caries. Consuming of pastries and other fancies shall be assessed as alimentary risk factor. Their excess can facilitate excessive body mass and in the future can cause many chronic non-infectious diseases (obesity, diabetes, atherosclerosis and etc.).

Analysis of confectionary and ice-cream consumption permits to assume that diet is overloaded with monosaccharide. Considering modern technologies, we can also speak about overloading by food ads.

Rather frequent consumption of fat-containing sauces permits to assume latent increase of fats' specific weight in eating. It results in increase of overloading with food ads, which are widely used in their production as well as in strengthening of chemical irritating impact of food. All these shall be assessed as alimentary risk factor.

Thus, analysis of some food products' consumption frequency permitted to find a number of gender distinctions, which characterize eating stereotype of modern schoolchildren, as well as to mark out alimentary 
risk factors, which require correction and prophylaxis. It should be pointed that sociological method of research is rather subjective. That is why its addition with objective methods, permitting to prove assumptions, can be rather promising. In context of health monitoring the preference shall be given to screening assessment.

Williams P. [43] carried out comparative analysis of Australian children and adolescents' breakfasts. He found that typical breakfast of young Australians was characterized by low content of fat, high content of carbonhydrates and sufficient quantity of thiamine, riboflavin, niacin, calcium and magnesium. If not to include cereals in breakfast the probability of the mentioned above elements' deficit increases. Regular breakfast is considered a sign of healthy eating. The received data are proved by results of other works [1, 12, 31].

Analysis of the so-called "food trash" consuming can serve as one more proof of earlier assumption about healthier eating of girls. Thus, analysis of "food trash” products' consumption brings us to the following conclusions:

- These products are rather frequent in diet, and their regular consuming shall be assessed as risk factor for digestion;

- Hygienic literacy of girls is much higher than boys'; it is proved by prevailing of girls' denials of such products;

- Propaganda of healthy eating is insufficient that conditions the demand in such measures' including in prophylaxis complex.

Analysis of eating organization in schools of province Bluefontane (South Africa) permitted for Meko L. et.al. [29] to conclude that its organization was unsatisfactory. As one of important risk factors for health they assessed prevailing of sweets, fast food and chips in diets.

During three weeks they conducted educational program devoted to eating in secondary school [22]. Effectiveness of these classes reflected in improvement of eating assessment and in more frequent consuming healthy food.

Loomes S., Croft A. [25] fulfilled analysis of Australian students' eating behavior. Besides, specificities of diet they studied the level of knowledge in this field, eating style (independent or at eating places), consumption of fast food, correlation with health indicators.

Concerning excessive body mass in respondents' families, these indicators are also important for assessment of correlations in system "eating-health". The received data shall also be estimated as additional risk factor: family and relatives greatly influence on schoolchildren's eating and eating behavior. If two generations of relatives have excessive body mass, its development in the third generation has probability of $100 \%$.

McCaughtry N., Fahlman M., Martin J. J., Shen B. [28] underline importance of educational programs in the field of eating for prophylaxis of obesity and preservation of health. Application of such program would facilitate the change of secondary school children's eating behavior.

Hopper C. A., Gruber M. B., Munoz K. D., Herb, R. A. [15] inform about significance of parents' participation in educational programs, devoted to healthy eating. Combination of school and family efforts permits to raise the level of knowledge in this field and facilitates optimization of schoolchildren's physical condition and physical fitness.

\section{Conclusions}

Thus, the received results prove validity of eating behavior studying in the frame of school age children health monitoring, considering its specific characteristics for creation of targeted prophylaxis programs. The found peculiarities of eating behavior permit to assess respondents' health as pre-nosological of alimentary genesis, which is reflected in excessive body mass, deficit of essential vitamins, mineral substances and food fibers, functional disorders of digestion. All these require working out targeted measures, directed at eating and alimentary status correction. Substantiation and working out of eating behavior objective criteria for adding of information about health; establishing of "feedback" of alimentary factor's influence on it are rather important and relevant tasks.

\section{Conflict of interests}

The authors declare that there is no conflict of interests.

\section{References}

1. Adolphus K, Lawton CL, Champ CL, Dye L. The Effects of Breakfast and Breakfast Composition on Cognition in Children and Adolescents: A Systematic Review. Advances in Nutrition: An International Review Journal, 2016; 7(3): 590S-612S. doi:10.3945/an.115.010256

2. Bodnar IR, Kindzera AB. Leisure of Ukrainian schoolchildren and place of motor functioning in it. Pedagogics, psychology, medical-biological problems of physical training and sports, 2016;5:11-18. doi:10.15561/18189172.2016.0502

3. Bordi PL, Cranage DA, Lambert C, Smith J. An Assessment of Middle School Children's Knowledge and Attitudes of Nutrition and Their Effects on Eating Behaviors. Journal of Culinary Science \& Technology, 2005;4(4): 1-15. doi:10.1300/J385v04n04 01
4. Bracale R, Milani Marin LE, Russo V, Zavarrone E, Ferrara E, Balzaretti C, ... Carruba MO. Family lifestyle and childhood obesity in an urban city of Northern Italy. Eating and Weight Disorders - Studies on Anorexia, Bulimia and Obesity, 2015;20(3): 363-370. doi:10.1007/s40519-0150179-y

5. Chang Y-J, Lin W, Wong Y. Survey on Eating DisorderRelated Thoughts, Behaviors, and Their Relationship with Food Intake and Nutritional Status in Female High School Students in Taiwan. Journal of the American College of Nutrition, 2011;30(1): 39-48. doi:10.1080/07315724.2011. 10719942

6. Coleman C, Wileyto EP, Lenhart CM, Patterson F. Multiple Health Risk Behaviors in Adolescents: An Examination of Youth Risk Behavior Survey Data. American Journal of Health Education, 2014;45(5): 271-277. doi:10.1080/1932 
5037.2014.933138

7. Diet, nutrition and the prevention of chronic diseases. Report of the joint WHO/FAO expert consultation. WHO Technical Report Series, No. 916 (TRS 916). Retrieved from http:// www.who.int/dietphysicalactivity/publications/trs916/en/

8. Dixit S, Singh JV, Kant S, Agarwal GG, Dubey A, Kumari N. A cross-sectional study on predictors and significance of eating behavior of adolescent girls. Vulnerable Children and Youth Studies, 2014;9(1): 10-16. doi:10.1080/17450128.20 13.804971

9. Duarte C, Ferreira C, Trindade IA, Pinto-Gouveia J. Normative body dissatisfaction and eating psychopathology in teenage girls: the impact of inflexible eating rules. Eating and Weight Disorders - Studies on Anorexia, Bulimia and Obesity, 2016;21(1): 41-48. doi:10.1007/s40519-015-0212-1

10.Fatemeh Balbasi, Ramin Shabani, Marzieh Nazari. Effect of high-intensity interval training on body composition and bioenergetic indices in boys - futsal players. Physical Education of Students, 2016; 5:42-48. doi:10.15561/20755279.2016.0506

11.Feldman RHL, Mayhew PC. Predicting Nutrition Behavior: The Utilization of a Social Psychological Model of Health Behavior. Basic and Applied Social Psychology, 1984;5(3): 183-195. doi:10.1207/s15324834basp0503_2

12.Galioto R, Spitznagel MB. The Effects of Breakfast and Breakfast Composition on Cognition in Adults. Advances in Nutrition: An International Review Journal, 2016;7(3): 576S-589S. doi:10.3945/an.115.010231

13. Giovanis Vasilios, Amoutzas Kiriakos, Vasileiou Efstathios, Ramadani Efstathia, Badas Efthimios. The diet of skiers with regard to the frequency of dinners. Physical Education of Students, 2013;6:96-102. doi:10.6084/m9.figshare.840511

14.Hart M. The importance and elements of healthy nutrition. Advances in Eating Disorders, 2016;4:(1): 14-30. doi:10.10 80/21662630.2015.1130536

15.Hopper CA, Gruber MB, Munoz KD, Herb RA. Effect of Including Parents in a School-Based Exercise and Nutrition Program for Children. Research Quarterly for Exercise and Sport, 1992;63(3): 315-321. doi:10.1080/02701367.1992.10 608748

16. Hummel E, Hoffmann I. Complexity of nutritional behavior: Capturing and depicting its interrelated factors in a causeeffect model. Ecology of Food and Nutrition, 2016;55(3): 241-257. doi:10.1080/03670244.2015.1129325

17.Humphries LL, Gruber JJ. Nutrition Behaviors of University Majorettes. The Physician and Sportsmedicine, 1986;14(11): 91-98. doi:10.1080/00913847.1986.11709225

18.Jagiello Marina, Jagiello Wladyslaw, Kozina ZhL. Differentiation of body composition of players of the polish national baseball team. Pedagogics, psychology, medical-biological problems of physical training and sports, 2014;10:45-51. doi:10.5281/zenodo.10502

19.Janina Olejnik B, Roszko-Kirpsza I, Marcinkiewicz S, Maciorkowska E. Uwarunkowania środowiskowe a stan odżywienia dzieci i młodzieży województwa podlaskiego [Environmental conditions and children's and youth's eating in Podliaska provine]. Pediatria Polska, 2012;87(1): 41-46. doi:10.1016/S0031-3939(12)70592-9

20.Jendrysek Marek, Nowosielska-Swadzba Danuta, Zwolinska Danuta, Podstawski Robert. Body composition of young people aged 17-18 years, practicing and not practicing swimming, with the use of the bioelectrical impedance method. Pedagogics, psychology, medical-biological problems of physical training and sports, 2015; 11:67-72. doi:10.15561/18189172.2015.1110

21.Jessa J, Hozyasz KK. Ocena sposobu żywienia dzieci kierowanych do oddziału pediatrycznego oraz wiedzy żywieniowej ich opiekunów - wyniki badania pilotażowego [Assessment of children's, directed to pediatric clinic eating and knowledge of their foster parents about eating - results of experimental study]. Pediatria Polska, 2016;91(3): 208213. doi:10.1016/j.pepo.2016.02.005

22.Kandiah J, Jones C. Nutrition Knowledge and Food Choices of Elementary School Children. Early Child Development and Care, 2002;172(3): 269-273. doi:10.1080/03004430212123

23.Kolokoltsev MM, Cieslicka Miroslawa, Muszkieta Radoslaw. Optimization of physical training of students of high school with regard to quantitative features muscular components of their bodies. Physical Education of Students, 2015;1:22-30. doi:10.15561/20755279.2015.0103

24.Kujawska-Pac U, Kwilosz E, Mazur A. Ocena żywności oferowanej w sklepikach szkolnych i kupowanej przez dzieci z krakowskich szkół podstawowych [Assessment of food products, offered in school shops and baught by children from Krakow primary schools]. Pediatria Polska, 2014;89(5): 347-351. doi:10.1016/j.pepo.2014.06.008

25.Loomes S, Croft A. An investigation into the eating behaviour of international students studying at an Australian university: should we be concerned? Journal of Higher Education Policy and Management, 2013; 35(5): 483-494. doi:10.1080 /1360080X.2013.825418

26. Martinchik AN, Maev IV, Ianushevich OO. Obshchaia nutriciologiia [General Nutrition], Moscow: MEDpressInform. 2005.

27.Marya Rehmani Ghobadi, Rastegar Hoseini. Investigating the effects of physical activity levels, dairy products and calcium intakes on risk factors of osteoporosis prevention in female students of Islamic Azad University of Damavand, Iran. Pedagogics, psychology, medical-biological problems of physical training and sports, 2014; 11, 79-82. doi:10.15561/18189172.2014.1114

28.McCaughtry N, Fahlman M, Martin JJ, Shen B. Influences of Constructivist-Oriented Nutrition Education on Urban Middle School Students' Nutrition Knowledge, Self-efficacy, and Behaviors. American Journal of Health Education, 2011; 42(5): 276-285. doi:10.1080/19325037.2011.10599198

29.Meko L, Slabber-Stretch M, Walsh C, Kruger S, Nel M. Nutritional environment at secondary schools in Bloemfontein, South Africa. South African Journal of Clinical Nutrition, 2015; 28(1): 53-54. doi:10.1080/160706 58.2015.11734527

30.Mustapic J, Marcinko D, Vargek P. Eating behaviours in adolescent girls: the role of body shame and body dissatisfaction. Eating and Weight Disorders - Studies on Anorexia, Bulimia and Obesity, 2015; 20(3): 329-335. doi:10.1007/s40519-015-0183-2

31.Njike VY, Smith TM, Shuval O, Shuval K, Edshteyn I, Kalantari V, Yaroch AL. Snack Food, Satiety, and Weight. Advances in Nutrition: An International Review Journal, 2016; 7(5): 866-878. doi:10.3945/an.115.009340

32.Oldewage-Theron, W, Egal, A. (2010 Nutrition knowledge and nutritional status of primary school children in QwaQwa. South African Journal of Clinical Nutrition, 23(3): 149-154. doi:10.1080/16070658.2010.11734329

33.Oosthuizen D, Oldewage-Theron W, Napier C. The impact of a nutrition programme on the dietary intake patterns of primary school children. South African Journal of Clinical Nutrition, 2011; 24(2): 75-81. doi:10.1080/16070658.2011. 11734354

34.Podrigalo LV, Danylenko GN. Donozologicheskiye sostoyaniya u detey, podrostkov i molodezhi: diagnostika, prognoz i gigiyenicheskaya korrektsiya [Prenosological 
condition in children, adolescents and young adults: diagnosis, prognosis and hygienic correction], Kiev: Geneza; 2014.

35.Podrigalo LV, Pashkevich SA, Prusik Krzysztof. Analysis of the relationship between food habits and health students. Physical Education of Students, 2012; 6, 83-87.

36.Pop Cristiana. Lucretia. Overweight and obesity risk assessment - two methods, different results. Physical Education of Students, 2016; 3: 43-52. doi:10.15561/20755279.2016.0306

37.Quattrin R, Toffolini L, Turello D, Calligaris L, Farneti F, Brusaferro S. Italian Public School: A Pilot Study about Disorders Related to Nutrition and their Management. Journal of the American College of Nutrition, 2008; 27(1): 75-79. doi:10.1080/07315724.2008.10719677

38. Schwarzer R, Richert J, Kreausukon P, Remme L, Wiedemann AU, Reuter T. Translating intentions into nutrition behaviors via planning requires self-efficacy: Evidence from Thailand and Germany. International Journal of Psychology, 2010; 45(4): 260-268. doi:doi.org/10.1080/00207591003674479

39.Sharkey JR, Haines PS, Zohoori N. Community-Based Screening: Association Between Nutritional Risk Status and Severe Disability Among Rural Home-Delivered Nutrition Participants. Journal of Nutrition For the Elderly, 2000; 20(1): 1-15. doi:10.1300/J052v20n01 01

40.Storozhik AI, Guligas AG, Tumanova VN. Dynamic of vertical stability indicators of junior schoolchildren, who have weakened hearing, under influence of physical education means. Pedagogics, psychology, medical-biological problems of physical training and sports, 2015;6:30-34. doi:10.15561/18189172.2015.0605

41.Turconi G, Guarcello M, Maccarini L, Cignoli F, Setti S, Bazzano R, Roggi C. Eating Habits and Behaviors, Physical Activity, Nutritional and Food Safety Knowledge and Beliefs in an Adolescent Italian Population. Journal of the American College of Nutrition, 2008; 27(1): 31-43. doi:10.1080/0731 5724.2008.10719672

42.Visser J, Notelovitz T, Szabo C, Fredericks N. Abnormal eating attitudes and weight-loss behaviour of adolescent girls attending a "traditional" Jewish high school in Johannesburg, South Africa. South African Journal of Clinical Nutrition, 2014; 27(4): 208-2016. doi:10.1080/16070658.2014.11734 511

43.Williams P. Breakfast and the diets of Australian children and adolescents: an analysis of data from the 1995 National Nutrition Survey. International Journal of Food Sciences and Nutrition, 2007;58(3): 201-216. doi:10.1080/09637480701198075

44.WMA Declaration of Helsinki - Ethical Principles for Medical Research Involving Human Subjects. Retrieved from: http://www.wma.net/en/30publications/10policies/b3/ index.html (access 01.07.2016)

\section{Information about the authors:}

Podrigalo L.V.; http://orcid.org/0000-0002-7893-524X; I.podrigalo@mail.ru; Kharkov State Academy of Physical Culture; Klochkovskaya str. 99, Kharkov, 61022, Ukraine.

lermakov S. S.; http://orcid.org/0000-0002-5039-4517; sportart@gmail.com; Kazimierz Wielki University in Bydgoszcz; Sport str. 2 , of.209, 85-064 Bydgoszcz, Poland.

Rovnaya O.A.; http://orcid.org/0000-0003-1519-5632; rovnayaolga@mail.ru; Kharkov State Academy of Physical Culture; Klochkovskaya str. 99, Kharkov, 61022, Ukraine.

Avdiievska O.G.; http://orcid.org/0000-0001-5764-5254; olena.avdiievska@karazin.ua; V. N. Karazin Kharkiv National University; 4 , Svobody Sq., 61022, Kharkiv, Ukraine.

Demochko H.L.; http://orcid.org/0000-0001-5744-5893; inio2@ukr.net; Kharkiv National Medical University; 4 Nauky Avenue, 61022, Kharkiv, Ukraine.

Cite this article as: Podrigalo LV, Iermakov SS, Avdiievska OG, Rovnaya OA, Demochko HL. Special aspects of Ukrainian schoolchildren's eating behavior. Pedagogics, psychology, medical-biological problems of physical training and sports, 2017;21(3):120-125. doi:10.15561/18189172.2017.0304

The electronic version of this article is the complete one and can be found online at: http://www.sportpedagogy.org.ua/index.php/PPS/issue/archive

This is an Open Access article distributed under the terms of the Creative Commons Attribution License, which permits unrestricted use, distribution, and reproduction in any medium, provided the original work is properly cited (http://creativecommons.org/licenses/by/4.0/deed.en).

Received: 12.02 .2017

Accepted: 25.02.2017; Published: 30.04.2017 